\title{
SPLIT-TYPE FRACTURES OF THE SPINE: A NEW MINIMALLY INVASIVE PERCUTANEOUS TECHNIQUE
}

\author{
FRACTURAS TIPO SPLIT DE LA COLUMNA: NUEVA TÉCNICA PERCUTÁNEA MÍNIMAMENTE INVASIVA \\ FRATURAS TIPO SPLIT DA COLUNA: NOVA TÉCNICA PERCUTÂNEA MINIMAMENTE INVASIVA

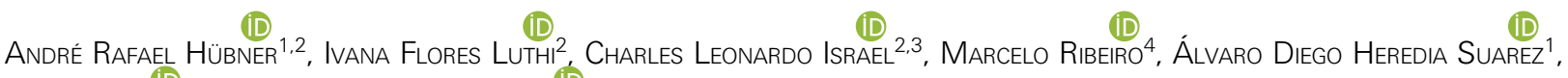

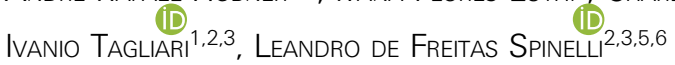

1. Hospital São Vicente de Paulo (HSVP), Orthopedic and Traumatology Institute (IOT), Passo Fundo, RS, Brazil.
2. University of Passo Fundo, Laboratory of Bioengineering, Biomechanics and Biomaterials, Passo Fundo, RS, Brazil.
3. University of Passo Fundo, Graduate Program in Design and Manufacturing Processes, Passo Fundo, RS, Brazil.
4. Kozma Clinic, Passo Fundo, RS, Brazil.
5. Federal University of Health Sciences of Porto Alegre, Department of Surgery, Porto Alegre, RS, Brazil.
6. Santa Casa de Misericórdia de Porto Alegre, Department of Orthopedics and Traumatology, Porto Alegre, RS, Brazil.

\begin{abstract}
Objective: This research presents a biomechanical analysis performed in the lumbar spine of a porcine animal model, considering a minimally invasive technique for the treatment of split fractures. Methods: Porcine spines were used to perform compression tests, considering three different approaches. Three groups were defined in order to verify and validate the proposed technique: a control group (1); spines with split fractures (2); and a treatment group (3). For the first group (control), spines were axially compressed until any kind of fracture occurred, in order to verify the strength of the structure. In the second group, split fractures were created to obtain the mechanical failure pattern of the model. In the third group, the split fractures were submitted to the proposed treatment, to verify the resistance achieved. The three groups were compared by means of axial compression tests. Statistical analysis was performed by ANOVA. Results: The control group (intact spine) and the treated split fracture group presented similar results $(p>0.05)$, differing from the results for the untreated split fracture group $(p<0.05)$. Conclusions: The tests performed in order to determine the behavior and strength of the lumbar spine when subjected to axial compression provided positive data for the development of a minimally invasive technique capable of restoring split fractures of the spine. Level of Evidence III; Experimental research.
\end{abstract}

Keywords: Spine; Spinal Injuries; Spinal Fractures; Therapeutics.

\section{RESUMO}

Objetivo: Esta pesquisa apresenta uma análise biomecânica realizada na coluna lombar em modelo animal suíno, considerando uma técnica minimamente invasiva para o tratamento de fraturas vertebrais do tipo split. Métodos: Foram usadas colunas de suínos para a realização de testes de compressão, considerando três diferentes abordagens. Para verificar e validar a técnica proposta, foram definidos três grupos: grupo controle (1); colunas com fraturas do tipo split (2) e grupo tratamento (3). No o primeiro grupo (controle), as colunas foram comprimidas axialmente até que ocorresse qualquer tipo de fratura, a fim de verificar a resistência da estrutura. No segundo grupo, foram criadas fraturas do tipo split para obter o padrão de falha mecânica do modelo. No terceiro grupo, as fraturas do tipo split foram submetidas ao tratamento proposto, para verificar a resistência alcançada. Os três grupos foram comparados por meio de testes de compressão axial. A análise estatística foi realizada por ANOVA. Resultados: O grupo controle (coluna íntegra) e o grupo com fratura do tipo split tratada apresentaram resultados semelhantes ( $p>0,05)$, diferentemente dos resultados do grupo com fratura do tipo split não tratada $(p<0,05)$. Conclusões: Os testes para determinar o comportamento e a força da coluna lombar quando é submetida à compressão axial forneceram dados positivos para o desenvolvimento de uma técnica minimamente invasiva capaz de restaurar fraturas tipo split da coluna vertebral. Nível de Evidência III; Pesquisa experimental.

Descritores: Coluna vertebral; Lesões da Coluna Vertebral; Fraturas da Coluna Vertebral; Terapêutica.

\section{RESUMEN}

Objetivo: Esta investigación presenta un análisis biomecánico realizado en la columna lumbar de un modelo animal porcino, considerando una técnica mínimamente invasiva para el tratamiento de fracturas vertebrales del tipo split. Métodos: Fueron usadas columnas de porcinos para la realización de tests de compresión, considerando tres diferentes abordajes. Para verificar y validar la técnica propuesta, fueron definidos tres grupos: grupo control (1); columnas con fracturas del tipo split (2) y grupo tratamiento (3). En el primer grupo (control), las columnas fueron comprimidas axialmente hasta que ocurriera cualquier tipo de fractura, a fin de verificar la resistencia de la estructura. En el segundo grupo, fueron creadas fracturas del tipo split para obtener el patrón de falla mecánica del modelo. En el tercer grupo, las fracturas del tipo split fueron sometidas al tratamiento propuesto, para verificar la resistencia alcanzada. Los tres grupos fueron comparados por medio de tests de compresión axial. El análisis estadístico fue realizado por ANOVA. Resultados: El grupo control (columna integra) y el

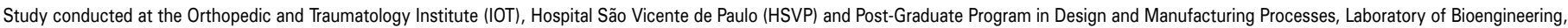
Biomechanics and Biomaterials, University of Passo Fundo, Rio Grande do Sul, Brazil.

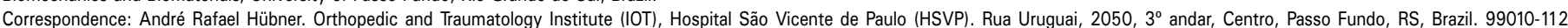
arhubner@terra.com.br, ahiotcoluna@gmail.com 
grupo con fractura del tipo split tratada presentaron resultados semejantes $(p>0,05)$, a diferencia de los resultados del grupo con fractura del tipo Split no tratada $(p<0,05)$. Conclusiones: Los tests para determinar el comportamiento y la fuerza de la columna lumbar cuando es sometida a la compresión axial suministraron datos positivos para el desarrollo de una técnica mínimamente invasiva, capaz de restaurar fracturas del tipo Split de la columna vertebral. Nivel de Evidencia III; Investigación experimental.

Descriptores: Columna Vertebral; Traumatismos Vertebrales; Fracturas de la Columna Vertebral; Terapéutica.

\section{INTRODUCTION}

The thoracolumbar region is the most frequent site of spinal fractures, especially at the T12-L1 level. ${ }^{1,2}$ Most of these fractures are caused by blunt trauma. ${ }^{3,4}$ In younger patients, thoracolumbar vertebral fractures are usually caused by high-energy accidents such as falls or motor vehicle accidents, while in elderly patients, the main etiology is osteoporosis. ${ }^{5}$ The annual incidence of thoracolumbar fractures is about 30 per 100,000 inhabitants. Among patients younger than 60 years of age, the annual incidence is about 13 per 100,000 , and it is twice as high in men as in women. ${ }^{6}$

Surgical treatment for fractures of the thoracolumbar spine, including split fractures, have traditionally been performed by instrumentation, promoting stability of the segments and giving integrity to the structure. A better understanding of the biomechanics of the vertebral segment, more precise classification of lesions, and the development of fixation systems that can improve mechanical stability, have enabled the current objectives for surgical treatment of fractures of the thoracolumbar spine to be achieved. In light of these problems, shorter instrumentation for preserving uninjured segments of the spine was previously presented, and numerical evaluation has been reported. ${ }^{7}$ Considering various research models. Busscher et al. published an extensive work emphasizing the importance of obtaining an animal model with human biomechanical characteristics for in vitro testing of the spine. The authors conclude that the porcine spine might be a good model for biomechanical studies of the human spine. ${ }^{8}$

The present study performs a detailed analysis of axial compression fractures in a porcine model, and analyzes, in particular, the behavior of spine fractures of the split type, when subjected to compression. It also analyzes the recovery of strength after the osteosynthesis with screws, performed using a percutaneous and minimally invasive method, to support a new surgical procedure for this specific type of fracture. The hypothesis is that osteosynthesis could be efficient in supporting stresses, and could, in some cases, prevent the need for open surgery and instrumentation.

\section{METHODS}

This research was approved by the Scientific Committee and the Research Ethics Committee of our University. Biomechanical tests were performed at the Laboratory of Bioengineering, Biomechanics and Biomaterials of our institution. Samples were prepared in advance at the laboratory of the University Hospital. All the spine models were analyzed by CT scan (Toshiba Aquilion 128-slice CT scanner) in order to verify the fracture patterns and the correct insertion site of the screws used to fix the fractures.

Considering that type A fractures (compression) occur more frequently in thoracolumbar vertebrae, especially in the lumbar segment, spine segments of the porcine model was adopted for the compression testing, corresponding to the set of vertebrae L2, L3 and L4. The animals were of the Landrace breed, with a mean age of 4.5 months and weight of approximately $120 \mathrm{~kg}$. Samples were obtained from a legally authorized sanitary fridge, and no living animal was handled in this research.

Vertebral segments $L 2$ to $L 4$ were used, to ensure that the ligaments and intervertebral discs of L3 vertebra were intact, as the joints will absorb energy before the occurrence of a fracture in the body of the L3 vertebra. Although there is a proportionately higher incidence of fractures of L1 in humans, we chose not to use the segment containing this vertebra. In that case, segments T12, L1 and $\mathrm{L} 2$ would be necessary, making it difficult to handle and place the implant in the porcine model due to the small space, considering that these vertebrae are very small. However, the lower lumbar spine provides larger vertebral bodies.

Considering the possibility of the spine buckling during the testing program, the height/diameter ratios (h0/d0) of ten specimens were tested by pilot-tests. These are presented in Table 1. It became clear that a device would be needed to take into account the buckling and stability of the specimens during the compression tests, since the mean relative h0/d0 obtained for these specimens showed an average ratio of 3:0. Although according to the literature, a ratio of between 2 and 3 is necessary for brittle materials, the values obtained were in the upper limit, and some precautions were necessary to maintain stability during the compression tests. In this case, the brittle material (vertebra) is covered by soft tissue.

A device was developed to ensure stability of the spine model, without buckling, at the start of load application (Figure 1A). Rods were fixed on each metal disk, to prevent buckling during the compression test. The rods were inserted in the spinal canal. The device was made from 304L stainless steel, as resistance to corrosion is needed when metal comes into contact with biological material. (Figure 1B) Figure $1 \mathrm{C}$ shows the vertebrae with the spinal canal prepared to receive the rods.

Given that there is no specific standard for compression testing

Table 1. Relationship between initial height and diameter of samples.

\begin{tabular}{c|c|c|c}
\hline Sample & Initial height $-\boldsymbol{h}_{\boldsymbol{o}}(\mathbf{m m})$ & Initial diameter $-\boldsymbol{d}_{\boldsymbol{o}}(\mathbf{m m})$ & $\boldsymbol{h}_{\boldsymbol{o}} / \boldsymbol{d}_{\boldsymbol{o}}$ \\
\hline 1 & 117.9 & 39.2 & 3.01 \\
\hline 2 & 116.4 & 38.4 & 3.03 \\
\hline 3 & 118.9 & 38.5 & 3.01 \\
\hline 4 & 118.9 & 40.3 & 2.95 \\
\hline 5 & 118.4 & 38.8 & 3.05 \\
\hline 6 & 117.2 & 39.5 & 2.96 \\
\hline 7 & 117.5 & 38.3 & 3.04 \\
\hline 8 & 116.8 & 38.3 & 3.07 \\
\hline 9 & 119.0 & 40.5 & 2.94 \\
\hline 10 & 118.9 & 38.5 & 3.10 \\
\hline
\end{tabular}
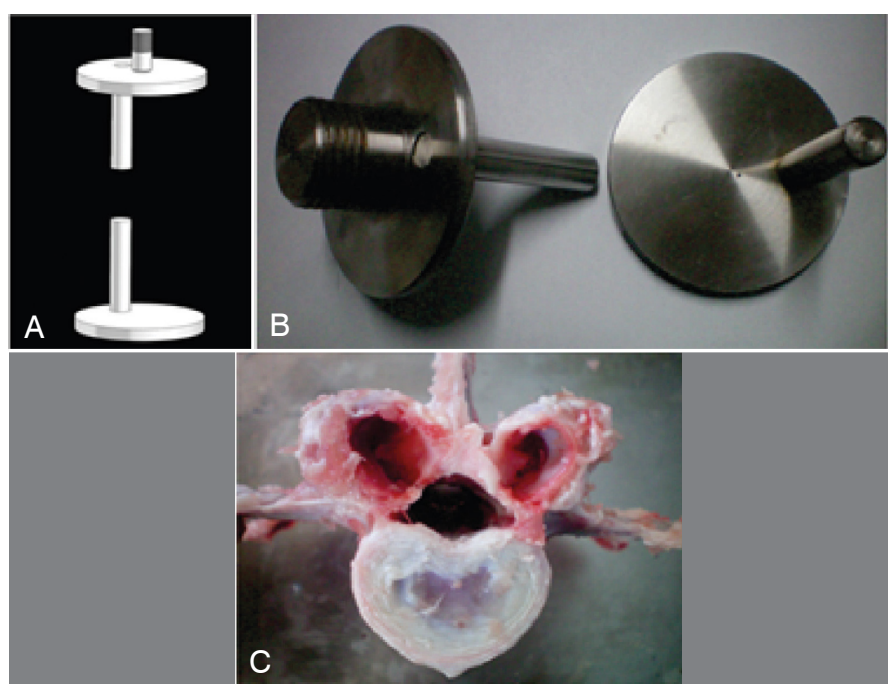

Figure 1. (A)1 Diagram of the device to be fixed in the compression equipment; (B) the developed device ready for use; (C) axial picture of vertebrae showing the medullary canal. 
on organic materials, we used ASTM F1717, which reports methods of static and fatigue tests on implants for the spine ${ }^{9}$ and ASTM E9-89a, which determines the compression testing of metallic materials. ${ }^{10}$ A Schenck universal compression-testing machine was used, with 20-ton capacity, coupled to a 2-ton load cell to measure the force applied during the tests. Figure 2 shows a spine sample during the compression tests.

\section{Study Groups}

The control group (Group 1) was performed with ten intact spine specimens. Group 2 was composed of six specimens in which split fractures were created in the L3 vertebra, but without performing osteosynthesis, in order to evaluate the resistance of the fractured spines (control 2). Group 3 was composed of six spine specimens in which split fractures were created in the L3 vertebra, followed by osteosynthesis in the central vertebra with two cannulated screws.

\section{Preparation of the split fractures and osteosynthesis}

Prior to the tests, each spine sample (composed of L2, L3 and L4 vertebrae, discs and ligaments) was cleaned (all medulla and other muscle tissues were removed); the samples were stored at a temperature of $-20^{\circ} \mathrm{C}$ until the tests. The samples were thawed at room temperature, in $0.9 \%$ sodium chloride (saline) solution to restore hydration.

The split fractures were created using an oscillating saw blade, following the entry angles, anterior to the pedicle, in order to obtain a sufficient volume of vertebral body to support the placement of the screws (in Group 3) or without synthesis (in Group 2). Figure 3A highlights the split fractures on the spine model.

After the fracture simulation, the samples of Group 3 were submitted to osteosynthesis. The technique consists of inserting two cannulated screws, one at each pedicle of the fractured vertebra, which will be used to perform compression of fracture. First, a 1.5 $\mathrm{mm}$ guide wire was placed in the pedicle, then a $2.5 \mathrm{~mm}$ diameter hole was drilled in the pedicle. Next, $3.5 \mathrm{~mm}$ cannulated screws ranging from 40 to $46 \mathrm{~mm}$ length were inserted (Synthes, Davos Platz, Switzerland). Figure 3B shows the sample with a guide wire going through the pedicles. Next, a hole was made using the drill. The approach to the fractured faces was visualized. Figure $3 \mathrm{C}$ shows two cannulated screws placed in the spine, and Figure 3D presents the compression of the fractured zone.

The samples were submitted to CT scans to see whether the screws were in the correct positions, i.e., that they reached the

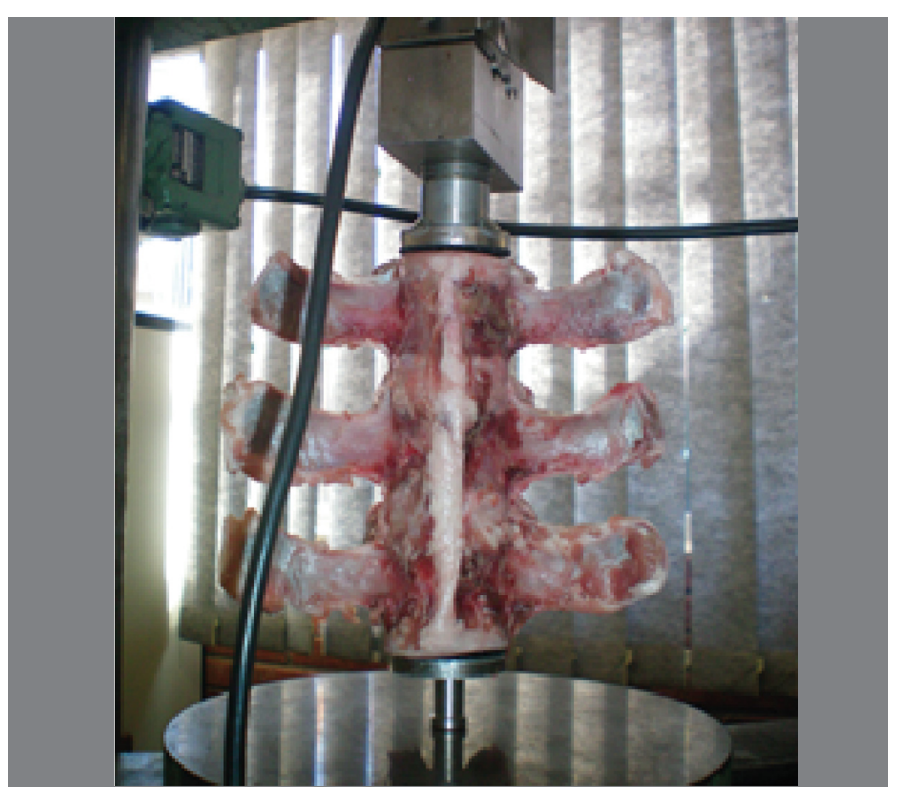

Figure 2. Spine sample during the compression test. fractured part of vertebral body $L 3$ and were not in the medullary cavity, outside the pedicle. The tests were only performed after osteosynthesis and posterior CT image analysis. Figure 4 shows the CT scan for Group 1 (control group)(A), Group 2 (split fracture)(B), and Group 3 (fracture with osteosynthesis)(C).

Statistical analysis was performed with SPSS 22, considering homogeneity tests and ANOVA. Differences between groups were considered statistically significant when $p<0.05$.

\section{RESULTS}

Figure 5 shows the maximum compression forces obtained for all groups, comparatively. There is a significant difference between Groups 1 and 2, but no difference between Groups 1 and 3 $(p>0.05)$, showing the efficacy of the proposed technique.

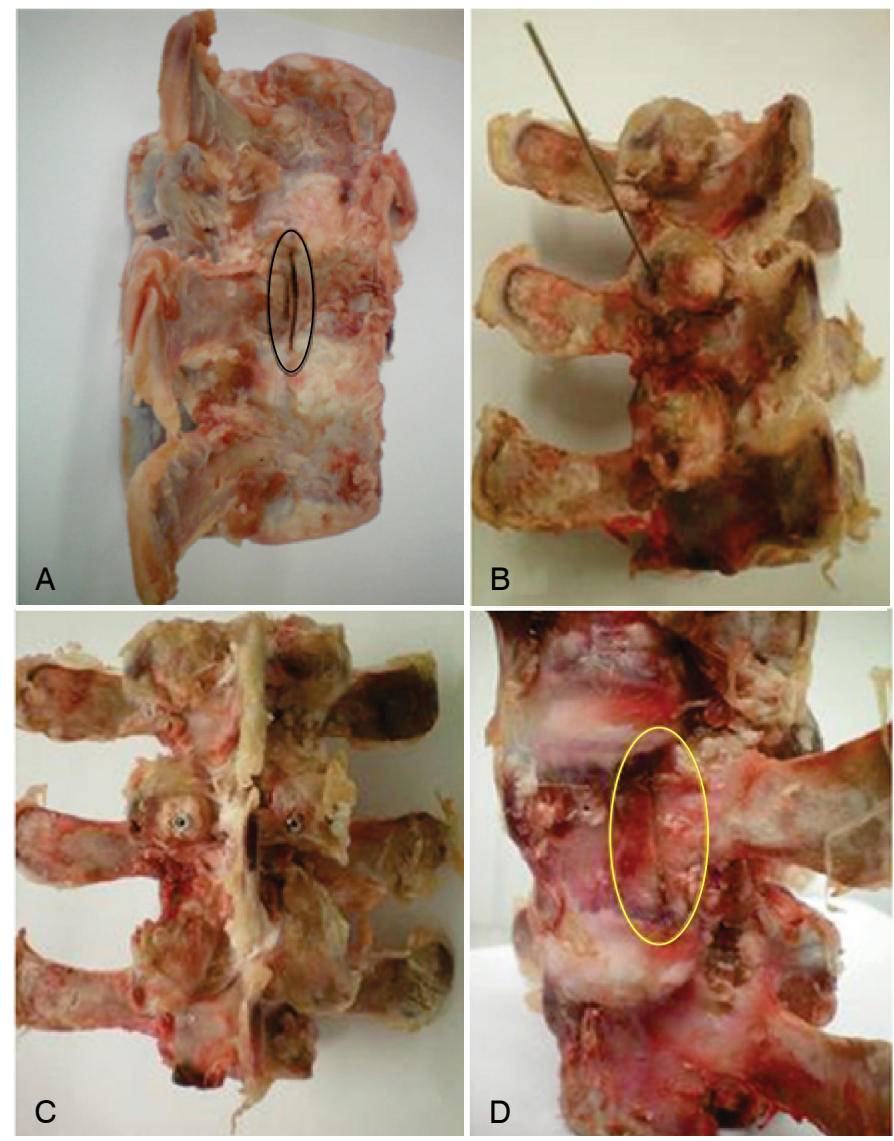

Figure 3. (A) Split fracture on L3; (B) placement of the wire guide; (C) placement of cannulated screws; (D) fixation of the fracture.
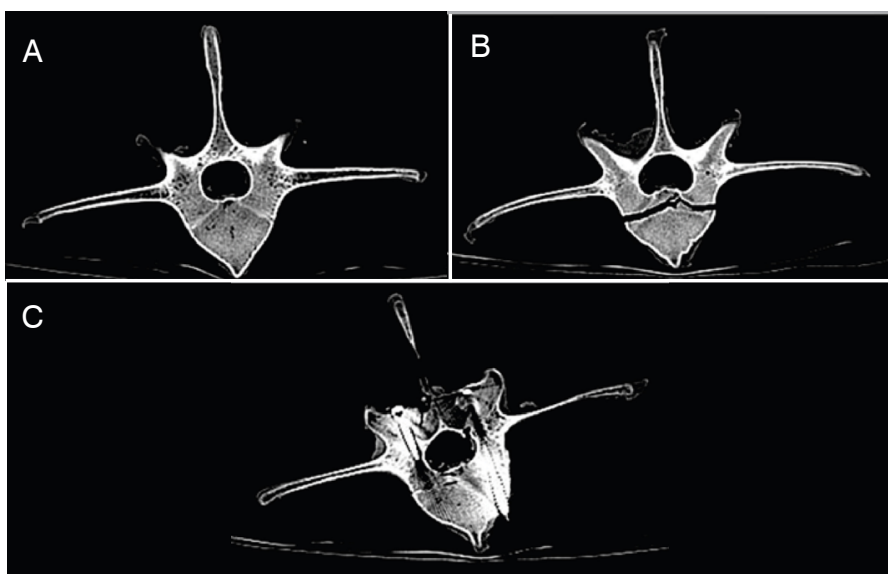

Figure 4. CT scans of samples: (A) Group 01; (B) Group 02; and (C) Group 03 


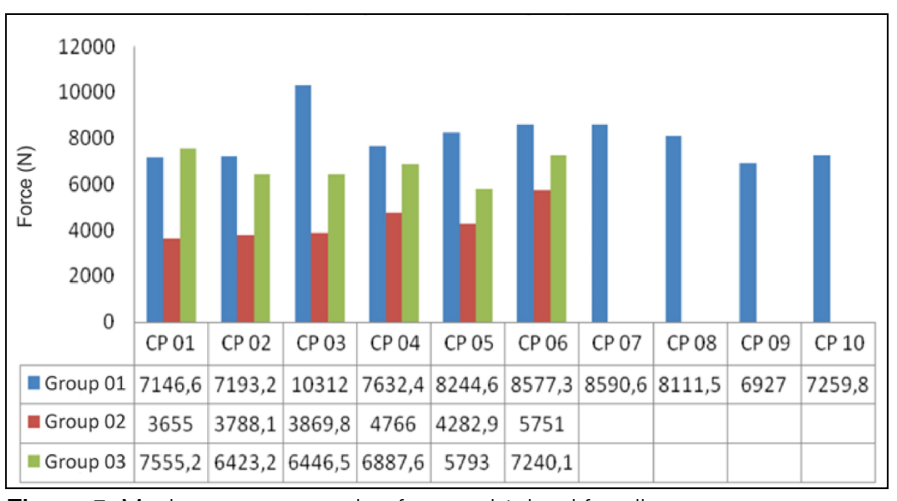

Figure 5. Maximum compression forces obtained for all groups.

\section{DISCUSSION}

This paper reports a detailed study of axial compression fractures in a porcine model, analyzing, in particular, the behavior of split-type spine fractures when subjected to compression. It analyzes recovery strength after osteosynthesis with screws using a percutaneous and minimally invasive method, with the aim of supporting a new surgical procedure for this specific type of fracture.

In biomechanics, the middle column is of little importance. However, at the moment of fracture, it can lead to retropulsion and may cause neurological impairment. Magerl et al. propose a classification based on the mechanics of the injury, indicating the force or moment applied on the injured vertebral segment. The three basic forces that produce injury are compression, distraction and rotation. Thus, the morphology of the fracture enables the pathogenesis of the lesion to be determined. ${ }^{11}$

Different treatment methods have been developed, but to date, there is no consensus on the ideal method for fracture fixation. Some authors recommend the posterior approach to the injured segment ${ }^{12}$ while others recommend the anterior approach. ${ }^{13} \mathrm{~A}$ combination of anterior and posterior approaches have also been recommended, based on biomechanical studies. ${ }^{14}$ These studies have shown that in the upright position, around eighty to ninety percent of the axial forces are absorbed by the front of the spine, while the posterior facet joints absorb the remaining ten or twenty percent. ${ }^{12-14}$

Split fractures were initially treated by conservative means. However, complications were observed, including nonunion due to migration of the anterior fragment and interposition of the disc, leading to a possible anterior arthrodesis surgery, increasing comorbidity and risks of deformity. ${ }^{15-17}$ The proposed minimally invasive technique could decrease comorbidity and invasiveness, without performing instrumentation that would reduce the function of articular segments.

Surgical treatment has been indicated for patients with neurological injury, spinal canal compression greater than $50 \%$, reduction in vertebral body height greater than $50 \%$, kyphosis of more than $30^{\circ}$ or vertebral translation, which is indirect sign of instability of the vertebral segment. Surgical treatment for fractures of the thoracolumbar spine, including split fractures, have been classically performed by arthrodesis, promoting fusion of segments and therefore, some integrity. $2,18-21$ A better understanding of the biomechanics of the vertebral segment, more precise classification of lesions, and the development of fixation systems that provide greater mechanical stability have enabled the current objectives for the surgical treatment of fractures of the thoracolumbar spine to be achieved. Thus, short arthrodesis for the preservation of uninjured segments of the spine was developed, 7,15 and this paper proposes a new approach for the split-type fracture.

Busscher et al. emphasize the importance of obtaining an animal model with human biomechanical characteristics for in vitro testing of the spine, for use in research into new implants and surgical procedures. The authors conducted studies and tests comparing load segments of porcine spinal cord with segments of human cadaveric spine. They also analyzed other studies in the literature that have already proven that the porcine anatomy best resembles the human anatomy, especially in terms of the size and orientation of the joints.
The authors concluded that the porcine spine might be a good model for biomechanical studies of the human spine. ${ }^{8}$ Therefore, it was used in the present work.

Using the numerical data obtained in the compression tests, it was possible to analyze the behavior of lumbar vertebrae considered normal (without fracture and with the intervertebral discs intact), vertebrae with split fracture, and lumbar vertebrae fractured by coronal division but restored using the new surgical technique proposed in this work. As bone material is fragile, we considered the maximum breaking strength of the specimens, which was highlighted for the purposes of comparison.

The compression tests in the first ten specimens of Group 1 demonstrated a certain reproducibility of the results, given that are variations among the specimens. All the samples come from an animal model (porcine), but despite the similar anatomy, there will always be some variations within the same species. Having obtained the maximum force values for Group 1, it was found that conducting the test on specimens before reaching their maximum rupture force presented drops in voltage throughout the loading. This drop occurs due to the presence of joints between the bodies of the vertebrae, with the intervertebral discs being ruptured before the bone fracture. Thus, each fibrocartilaginous plate of the disc is absorbing a certain amount of load (data not shown). When the load required to break a plate is reached, the plate breaks and causes a force-resisted force to fall. This process occurs until the entire fibrous ring is ruptured and compressed, leaving only bone to absorb the compression forces, until fracture occurs. This occurrence was also observed in the second and third groups.

The significant difference between Groups 1 and 2 was expected, given that the specimens of the two groups had different characteristics. In Group 1 the samples were intact, as the aim was to characterize the compression effort in the lumbar vertebrae, and in the Group 2 the samples presented split-type fracture.

The aim of the compression tests performed on the six test specimens of Group 3 was to obtain numerical data for analyzing the response of the new minimally invasive surgical technique, through the application of two cannulated screws in the pedicles of the segments of lumbar vertebra fractured by coronal division (split fractures). The statistical analysis of Groups 2 and 3 showed statistically significant difference between the two groups in relation to maximum rupture strength. However, there were no differences between Group 1 and Group 3, demonstrating the efficacy of the new surgical technique.

There are some limitations in our study, including the small number of specimens, and the fact that it does not consider dynamic loading. However, pilot tests have shown low standard deviation, with reproducibility being observed. All specimens containing osteosynthesis were previously evaluated by tomography, to verify the correct positioning of the screws, in order to avoid biases. Static and progressive loading were initially considered in order to standardize the tests. Dynamic tests were also carried out, and will be presented in future works. Nevertheless, the research shows a clear differentiation between Groups 1 and 2 and between Groups 2 and 3, but demonstrates the similarity between Groups 1 and 3. Patients have been treated using the technique, demonstrating its efficacy; the results of these procedures will be presented in future works.

\section{CONCLUSION}

We present positive arguments in favor of a new minimally invasive surgical technique for restoration of vertebrae fractured by coronal division (split fractures). Analysis of variance showed no significant difference between the intact and treated groups, demonstrating that this technique is a viable and economical option for the treatment for the split fractures, considering minimally invasive surgery.

All authors declare no potential conflict of interest related to this article. 
CONTRIBUTION OF THE AUTHORS: This manuscript, which is a study by the Hospital São Vicente de Paulo, the Institute of Orthopedics and Traumatology, and the University of Passo Fundo, RS, has seven authors. Each author made significant individual contributions to this manuscript. ARH, IFL, CLI, ADHS, IT, LFS performed the bibliographic research, writing of the manuscript, and the mechanical tests. MR assisted in the application of the CT tests. All authors reviewed the manuscript and contributed to the intellectual concept of the study.

\section{REFERENCES}

1. Denis F, Armstrong GW, Searls K, Matta L. Acute thoracolumbar burst fractures in the absence of neurologic deficit: a comparison between operative and nonoperative treatment. Clin Orthop Relat Res. 1984;(189):142-9.

2. Singh K, Kim D, Vaccaro AR. Thoracic and lumbar spinal injuries. In: Herkowitz HN, Garfin SR, Eismont FJ, Bell GR, Balderston RA (eds). Rothman-Simeone: the spine. Philadelphia: Saunders Elsevier; 2006. p. 1132-3

3. Kanis JA, Johnell O, Oden A, Sembo I, Redlund-Johnell I, Dawson A, et al. Long term risk of osteoporotic fracture in Malmo. Osteoporos Int. 2000;11(8):669-74. doi: 10.1007/ s001980070064

4. Kannus P, Niemi S, Parkkari J. Continuously increasing number and incidence of fallinduced, fracture-associated, spinal cord injuries in elderly persons. Arch Intern Med. 2000:160(14):2145-9. doi: 10.1001/archinte.160.14.2145.

5. Robertsson A, Branfoot T, Barlow F, Giannoudis P. Spinal injury pattern resulting from car and motorcycle accidents. Spine (Phila Pa 1976). 2002;27(24):2825-30. doi: 10.1097/00007632-200212150-00019.

6. Jansson KA, Blomqvist P, Svedmark P, Granath F, Buskens E, Larsson M, et al. Thoracolumbar vertebral fractures in Sweden: an analysis of 13,496 patients admitted to hospital. Eur J Epidemiol. 2010:25(6):431-7. doi: 10.1007/s10654-010-9461-5

7. Hubner AR, Gasparin D, Meira Junior AD, Israel CL, Dambros JM, Ribeiro M, et al. Numerical analysis of multi-level versus short instrumentation for the treatment of thoralumbar fractures. Eur J Orthop Surg Traumatol. 2015;25(Suppl 1):S213-7. doi: 10.1007/s00590015-1612-7.

8. Busscher I, Van der Veen AJ, Van Dieën JH, Kingma I, Verkerke GJ, Veldhuizen AG. In vitro biomechanical characteristics of the spine: a comparison between human and porcine spinal segments. Spine. 2010;35(2):E35-42. doi: 10.1097/brs.0b013e3181b21885.

9. American Society for Testing and Materials. ASTM F1717. Standard test methods for spinal implant constructs in a vertebrectomy model. 2009
10. American Society for Testing and Materials. ASTM E9-89a. Standard test methods of compression testing of metallic materials at room temperature. 2000

11. Margerl F, Aebi M, Gertzbein SD, Harms J, Nazarian S. A comprehensive classification of thoracic and lumbar injuries. Eur Spine J. 1994;3(4):184-201. doi: 10.1007/BF02221591.

12. Stauffer ES. The use of the $A O$ 'fixateur interne' for thoracic and lumbar fractures. In: Bridwell KH DeWald RL (eds). The textbook of spinal surgery. Philadelphia: JB Lippincott; 1997. p. 1949-55.

13. Aebi M. Operative behandlung von wirbelsfrakturen-dorsale oder ventral instrumentation. OP J. 1996;12:182-7.

14. Harms J. Screw-threaded rod system in spinal fusion surgery: state of the art review. Spine. 1992:6:541-77.

15. Chen F, Kang Y, Li H, Lv G, Lu C, Li J, et al. Treatment of lumbar split fracture-dislocation with short-segment or long-segment posterior fixation and anterior fusion. Clin Spine Surg. 2017;30(3):E310-6. doi: 10.1097/BSD.0000000000000182.

16. De Boeck H, Opdecam P. Split coronal fractures of the lumbar spine. Treatment by posterior internal fixation and transpedicular bone grafting. Int Orthop. 1999;23(2):87-90. doi: $10.1007 /$ s002640050314.

17. Kim BG, Dan GM, Shin DE. Treatment of thoracolumbar fracture. Asian Spine J. 2015;9(1):133-46. doi: 10.4184/asj.2015.9.1.133

18. Bradford DS, Akbarnia BA, Winter RD, Seljeskog EC. Surgical stabilization of fractures and fracture-dislocations of the thoracic spine. Spine J. 1977;2(3):185-96.

19. Levine AM, Edwards CC. Low lumbar burst fractures. Reduction and stabilization using the modular spine fixation system. Orthopedics. 1988;11(10):1427-32.

20. McAfee PC, Bohlman HH, Yuan HA. Anterior decompression of traumatic thoracolumbar fractures with incomplete neurological deficit using a retroperitoneal approach. J Bone Joint Surg Am. 1985:67(1):89-104

21. Mumford J, Weinstein JN, Spratt KF, Goel VK. Thoracolumbar burst fractures. The clinical efficacy and outcome of nonoperative management. Spine (Phila Pa 1976). 1993;18(8):955-70. 